\title{
HoMOgENEITY, HETEROGENEITY, THE Supply Curve, and Consumer Theory
}

\author{
Igor WYSOCKI AND WaLter E. Block
}

\begin{abstract}
In this paper we try to wrestle with the triviality objection to the concept of the same good. If we define two resources as serving the same list of ends, then whether these items can be subsumed under the rubric of the "same good" revolves around how we conceive of ends. If ends are at least partly language-dependent, that is, the way of individuating ends depends on the level of generality with which we refer to them, then the notion of the same good seems trivial. In extreme cases, we can specify ends in such a manner that no two items would fall into the-same-good category. Or, we can construe ends so generally that all resources would be conceptualized as the same good for they would serve the same general ends; e.g., of benefitting their owners. After presenting the problem in detail, we study the implication of our construal of ends. We conclude by showing that the triviality objection cannot undermine Austrian subjectivism.
\end{abstract}

KEYWORDS: supply curve, homogeneity, heterogeneity, consumption, consumer theory

JEL CLASSIFICATION: B53, D11

Igor Wysocki (igorwysocki82@wp.pl) is an independent scholar in Poland. Dr. Walter Block (wblock@loyno.edu) is Harold E. Wirth Eminent Scholar Endowed Chair and Professor of Economics at Loyola University-New Orleans.

The authors wish to thank a helpful referee, who greatly improved this paper. The usual caveat applies: all remaining errors and infelicities are our own responsibility. 


\section{INTRODUCTION: STATING THE PROBLEM}

The problem of the triviality objection has already been hinted at (Wysocki and Block, 2018), in which these authors suggest an improvement on Machaj's (2007, p. 236) contention that: "We recognize some things as 'supplies,' because we realized they could serve the same end." What Wysocki and Block offered instead was:

We claim that Machaj's grain of analysis is too crude to capture the concept of the same good. For let us imagine that an economic actor is confronted with a car and a scooter. Obviously, the two serve some common ends. Yet, unless the actor is blinded to the non-overlapping ends both serve, he would falsely treat them as the same economic good. If an actor's crudely described end is to travel from A to B without specifying either the velocity of the travel or the overall comfort thereof, can these two (with a huge stretch of imagination) be considered two units of the same good?

On the face of it, it appears to be a satisfactory rebuttal of Machaj's position. The fact that two items satisfy the same end is insufficient to make them the same economic good for there can be other non-overlapping ends they can serve, which would effectively make them distinct economic goods. So far, so good. Yet, there is a crucial intervening factor that is easy to miss. For the question arises: how do we construe ends; or, more precisely, how do we individuate ends? What level of specificity should be involved in individuating them? The proper way of referring to ends is no trivial matter because we are going to arrive at different conclusions as to a list of ends depending on how specifically/ generally they are described. ${ }^{1}$

In Section II we attempt to sharpen the formulation of the problem. The burden of Section III is to study the implications of the framework of ends and choices we propose here. In Section IV

\footnotetext{
${ }^{1}$ We should bear in mind that ends, being mentally envisaged, are described in intensional terms. For instance, when we have a need to go to a cinema to see a film, what would satisfy this need is at least some set of action-tokens. It could be a film $F_{1}$ in cinema $C_{1}$ or film $F_{2}$ in cinema $C_{2}$ etc. Our ends are rarely if ever specific as to be satisfied by only one action token. This fact allows us for referring to ends in intensional, rather than extensional, terms, which, in turn, gives rise to our problem of ends being at least party language-dependent.
} 
we explain why the notion of supply must be relative to a given economic actor. We conclude in Section V.

\section{SHARPENING THE FORMULATION OF THE PROBLEM}

Let us illustrate our above rather abstract considerations. To give the triviality objection as sharp a formulation as possible, we make these two claims:

1) we can pick such ways of referring to ends that would necessarily render all resources as the same economic good (the same supply) and,

2) alternatively, we can choose such ways of referring to ends that would necessarily render all resources as distinct economic goods.

Both outcomes seem highly unwelcome. The first would render the predicate "the same economic good" utterly useless, for this relation would be always instantiated between any two resources (objects) to which we can refer. Hence, the predicate "the same good" would be utterly uninformative and therefore useless. It would be impossible to think of at least one pair of objects such that the relation of "the same good" does not hold between them. There is a rule in logic to the effect that if there is no object that this predicate does not apply to, then the predicate is dispensable for it does not refer to any distinctive property. After all, ex hypothesi, all the objects share it.

The second, on the other hand, renders "the same economic good" a relation sui generis, something which closely resembles the relation of identity. It would follow that the relation of the same economic good would divide the universe of resources into non-overlapping one-item categories. There would not be any two distinct objects that could instantiate the relation of the same economic good. In other words, such a concept of the same good would render as many singletons as there are individual physical objects. ${ }^{2}$ Then, the notion of supply would not make any

\footnotetext{
${ }^{2}$ There would be an indefinitely large number of these, but not an infinite one. This is because for Austrian economists, resources are discrete, not infinitesimally small. That is, strictly speaking, no supply curve, nor any on the demand side
} 
sense at all. There would always be only one element in the supply of any good.

Let us now illustrate how ends should be specified to arrive at our two-equally unwelcome-outcomes. First, for everything to stand in relation of "the same economic good" to everything else (and to itself!), we must refer to ends in most general terms possible. One such example is "to satisfy a need" (Wysocki and Block, 2018). When we choose such a criterion for identifying ends, then, trivially, everything that counts as an economic good satisfies that criterion, for it consists of the satisfaction of a need that distinguishes economic goods from all other matter. In this extreme case, we would end up with a supply of one economic good. The point is, all economic goods necessarily satisfy a need, otherwise, they would not be found in this category. ${ }^{3}$ Given such a level of specificity of ends to satisfy, cars, women, films and music would be economically indistinguishable.

Now let us turn to illustrating how we can end up with each economic good constituting a distinct one from all the others, which is a situation of economic goods being as numerous as resources. Here, the whole universe of economic goods ordered by the thus conceived relation of sameness would yield sui generis sets. Each would contain only one economic good. There would be no two goods that would be considered identical; e.g., as part of the same supply. It is not difficult to determine how to yield such an outcome. It is enough to describe an end so specific that only one

either, are smooth, and thus differentiatable or integrateable. For a praxeological criticism of mathematics in mainstream economics that would deny this contention, see Anderson (2001, 2002); Barnett (2003, 2004); Barnett and Block (2006, 2010); Bratland (2000); Bylund (2011); Callahan (2001); Cachanosky (1985, 1986); Hazlitt (1959); Herbener (1996); Hutt (1979); Jablecki (2007); Kirzner (1990); Leoni and Frola (1977); Levinovitz (2016); Menger (1973); Mises (1977, 1998 [1949]); Murphy (2008); Murphy, Wutscher and Block (2010); Pfleiderer (2014); Reekie (1984a, 1984b); Rizzo (1979b); Röpke (1956); Rothbard (1960, 1988, 1993, 1997b, 2011a, 2011b); Shostak (2002); Spadaro (1956); Syrios (2017); Wolfram (2002); Wutscher (2005).

${ }^{3}$ Logical positivists would dismiss this claim as a mere tautology. We claim, in contrast, that it is, instead, a synthetic a priori insight. For more on this see Block (1973, 1980, 1999), Batemarco (1985), Fox (1992), Hoppe (1989, 1991, 1992, 1995), Hülsmann (1999), Mises (1969, 1998 [1949]), Polleit (2008, 2011), Rizzo (1979b), Rothbard (1951, 1957, 1960, 1971, 1973, 1993, 1997a, 1997b, 1997c, 1997d), Selgin (1988), Wiśniewski (2014). 
resource can fit the description. For instance, let us consider an end such as "quenching thirst at a unique place," with the location being specified in terms of Cartesian coordinates. Our entire supply would then be the universe of drinks at this precise spot. ${ }^{4}$ But now, alas, each of them constitutes a different economic good. In this situation, we cannot speak of $a$ supply of drinks but rather of as many supplies of drinks as there are drinks (as understood as physical objects) and as many spots or places there are in the universe. What is more, equipped with such a finely-grained conceptual apparatus, we can finally do justice to Machaj's (2007) intuition that a wedding ring on your fiancée's finger is a distinct economic good from all the other wedding rings physically indistinguishable from that one. Now, we can render Machaj's insight trivially true by calibrating the level of specificity/generality of an end that the rings are supposed to serve. To make the ring actually given to a fiancée economically distinct from all the other physically identical rings, the specification of an end should run along, more or less, these lines: "to derive satisfaction from an actual fact of receiving a gift from a loved one."

With the distinction between potentiality and actuality, we can easily make any otherwise physically identical stack of items economically distinct. At the very least, such a stack would split into two distinct classes of economic goods, with one a mere singleton containing the ring actually given as a gift. That is, one class would be a singleton encompassing an actually given ring, while the other ones would include all the other physically identical wedding rings. The same would apply to any other type of item in question..$^{5}$ An actually received book can (on this account) be considered a different economic good from its identical copies, or counterparts, etc.

\footnotetext{
${ }^{4}$ Assuming that there are non-drinks that we can economize under such circumstances, there must be some other criterion to single out other economic goods in this example. Yet, the point remains valid: with an end specified in such a manner, all the drinks are economically distinct.

${ }^{5}$ Similarly, we can attain this end simply by resort merely to geographical space. No two things can occupy the same exact location. Therefore, all rings, or anything else for that matter, necessarily occupy different places in the universe. No matter how identical they may be in other regards, in this one they are different. Hence, each constitutes the supply of a separate good.
} 
As an aside, it is worth noticing that the actuality/potentiality distinction applied as a criterion to determine whether a heap of items are the same economic goods or not closely resemble the well-identified fact that that two goods are the same economic good cannot be by any means demonstrated in action (Wysocki and Block, 2018). Action is analogous here to actuality and prior-to-actual-choice situation is analogous to potentiality. It has been long recognized by Block ${ }^{6}$ that there can be no indifference demonstrated in action. ${ }^{7}$ Now, we can see which assumption lay behind Block's contention: he believed (and made it explicit) that when we are confronted with a heap of physically identical items and we happen to pick up a particular one, the inference is that the one actually picked up immediately starts constituting a different economic good, distinct from the ones we did not choose. Seen in this light, it is no surprise that Block maintained ${ }^{8}$ that a bunch of identical dollar bills are the same economic goods before action, but then split into two classes of distinct economic goods once a particular dollar bill has been picked up; e.g., for the purpose of making payment. However, we can specify serviceability in such a manner that actuality (an actual choice) plays no role. For example, we would be inclined to say that this bunch of dollars are all the same economic good whether they were acted upon or not because we construe their serviceability only as a potential. That is, even if we choose a particular dollar, we can claim that equally well any other dollar could have been picked up and that is why they are economically on a par. This counterfactual statement cannot be demonstrated in action either, but the relation of sameness between economic goods does not yield itself to demonstration easily.

\section{IMPLICATIONS OF SPECIFYING ECONOMIC GOODS IN TERMS OF DIFFERENTLY CONSTRUED ENDS THEY SERVE}

Since we established (or stipulated?) that whether two goods fall into the same-good category depends on at what level of

\footnotetext{
${ }^{6}$ Block (2009), Block and Barnett (2010).

${ }^{7}$ And so the fact that two resources are the same economic goods cannot by the same token be demonstrated via human action.

${ }^{8}$ See fn. 9, supra.
} 
generality we specify the ends they respectively serve, we are now ready to carry on with our agenda and study the implications of our concept of supply and hence the supply curve.

First of all, we posit that whether two items represent the same economic good always depends on how a given economic actor envisages his ends. This, in turn, implies that there can be no intersubjectively correct answer to the question of whether two physical goods can be subsumed under the category of the same good. For the answer thereto is always contingent upon the way of referring to an actor's ends. Or, in other words, the decisive factor is the way an actor mentally frames his choices. For instance, consider a person who envisages his choices (in intensional mental terms) as (in the descending value scale):

1. Going to a cinema with a woman

2. Playing football with friends

3....

Taking this description seriously, we must conclude that (prior to taking any real action), any ordered pair $(a, b)$, where $a$ stands for cinemas and $b$ stands for the companionship of women, would do equally well. That is, as envisaged, there would be no real choice ${ }^{9}$ between cinemas and neither would there be between accompanying women as the use of an indefinite article suggests. After all, an economic actor frames his most important end as going to $a$ cinema with $a$ woman. This implies that it is any cinema and any woman in combination that would allow this economic actor to achieve his end. Economically speaking, all female companionship falls into the same class (they constitute one and the same supply for this actor) and the same applies to available cinemas. ${ }^{10}$ What

${ }^{9}$ At least as believed by this actor. Equivalently, we might say that the actor believes that any cinema is as good as any other and the same applies to the companionship of women. Technically speaking, all available cinemas would constitute the same economic good and all female companionship also fall into one and the same class of economic goods-though that class is obviously distinct from a class of the cinemas mentioned earlier.

${ }^{10}$ There can be an interesting objection raised against us; that is how we do know that in our scenario female companionship and cinemas constitute distinct economic goods? After all, both female companionship and cinemas contribute to the satisfaction of this end and our very criterion of distinguishing between different 
is more, any pair instantiating the generically described action of going to a cinema with a woman would be preferred to any actiontoken exemplifying playing football with friends.

However, undeniably, the choice specification may be subtler. To that effect, consider what follows:

1. Going to cinema $C$ with $a$ woman

Now, no other cinema than $C$ would do equally well although the actor still considers the companionship of all available women as constituting the same economic good. Now, any ordered pair $(C, b)$, where $C$ is a proper name of that given cinema, and $b$ again ranges over some universe of available women would be, from the point of view of the actor in question, as good as any other, which implies that all available female companionship falls into the category of the same economic good.

Finally, an end may be specified as specifically as possible, e.g.

1. Going to cinema $C$ with a woman $W$, traveling along the road $R$

Now, any means contributing to that end are necessarily heterogeneous; that is, it is only cinema $C$, woman $W$ and road $R$ that will do. No other alternatives are equally good. It follows that cinema $C$ is economically distinct from any other cinemas available, and the

economic goods is by consulting which ends (given by intensional descriptions) a given means can satisfy. Now, if it were the case that the only end a cinema can satisfy is to go with a woman thereto and the only end female companionship can satisfy is go to a cinema so accompanied, we would apparently be at a loss. For it would then be the case that the ends served by the two would be co-extensive and therefore equivalent. In the absence of cinemas, female companionship would cease to be an economic good; whereas in the absence of female companionship, cinemas would lose their economic character; nay, they would even lose the character of a good-they would then be useless. Our reply is two-fold. First of all, even if co-extensive, these two economic goods would be accounted for by different descriptions: cinemas would still serve as a place to take a woman, while female companionship would serve to go to a cinema so accompanied. Even if services are co-extensive (if female companionship is an economic good, you take the woman to a cinema; and when a cinema is an economic good, you go there with female companionship), these two rather constitute perfectly complementary goods. Second, and less philosophically, our economic actor could easily envisage some ends female companionship can satisfy outside cinemas, which would conclusively render cinemas and female companionship economically distinct. 
same point holds for women and roads. Summarizing, whether any given pair of goods are in the same supply depends on how a given economic actor frames his ends. A pair of items would thus constitute the same economic good relative to one way of describing ends but not from the other.

\section{WHY THE NOTION OF SUPPLY MUST BE RELATIVE TO A GIVEN ECONOMIC ACTOR}

First, it must be noted that since we construe of the same economic good as encompassing the items that are believed by an economic actor to serve the same ends (goals being framed by that actor himself), physical sameness does not readily translate into economic identity (see: Machaj's example of a wedding ring). What is more, belonging to the category of the same economic good could be imputed by an actor on items of different physical constitution since he might find them equally serviceable with respect to some end, as specified by him. In other words, there are no implications at work here: physical and economic sameness are not synonyms.

The correct inference from the above consideration is that a notion of a supply cannot be constructed along the lines of physical sameness. It is simply not necessarily the case that a stack of physically identical items would always constitute one and the same supply. Let us consider persons $A$ and $B$ and their respective, mentally framed, ends. $A^{\prime}$ s end is to travel from $C$ to $D$ (at any velocity, under any circumstances); whereas $B^{\prime}$ s goal is to depart from $C$ and arrive at $D$ with a velocity ranging from $80-100 \mathrm{mph}$. Certainly, different items would satisfy these respective ends. $A$ would find all vehicles equally serviceable; whereas $B$ would make some finer distinctions; that is, a car would do for him but not a bike or a plane for that matter. Since for these two persons, the items falling under the category of the same economic good would differ, we cannot stack those clearly distinct supplies on a two-person scale, let alone draw up a supply curve taking into account the both of them. What is worse, one man's meat is another man's poison. It can turn out to be the case that an item which is an economic good for $A$ constitutes an economic bad for $B$ or vice versa, which would again preclude the derivation of any social notion of the supply. Therefore, given that, it seems that our 
two extremes alluded to in the introductory section can be exemplified. There can be an individual for whom all goods would be perfectly heterogeneous, while there can be another one for whom everything is economically the same.

If we are to escape from the Scylla of only one good, and the Charybdis of an indefinitely large number of them, we must resort to Austrian subjectivism. ${ }^{11}$ That is to say, for some people, cars, female companionship, films and music are the same good. For others, for most of us, this is just plain silly. Thus, there is no one right way to determine the supply of a good. It varies from person to person, and, for each individual, it varies over time, as tastes change.

Precisely the same dilemma confronts advocates of antitrust lawsuits under neoclassical monopoly theory. The plaintiff ${ }^{12}$ wants to define the industry as narrowly as possible, so that the concentration ratio can be maximized. For him, the desiderata are not all food, nor all breakfast food, nor all cereal, nor, even, all dry cereal. In his view, even further industrial considerations must be employed, for example, whether the product includes sugar, or raisins, or anything else he can think of to raise the concentration ratio. In sharp contrast, the defendant desires as wide as possible a definition, so that the concentration ratio vanishes into thin air. For this side of the lawsuit, cars, female companionship, films and music will do just fine, and, even better if ski vacations, violins, bananas, shoe laces, etc., are tossed into the mix as well. So, who is correct? The plaintiff or defendant? The response emanating from the subjectivist economist is, don't be silly. Any answer will necessarily be arbitrary. And yes, as the entire antitrust philosophy requires a coherent response to this challenge, it, too, must be jettisoned. ${ }^{13}$

${ }^{11}$ States Hayek (1979, p. 52): "And it is probably no exaggeration to say that every important advance in economic theory during the last hundred years was a further step in the consistent application of subjectivism." Also, see the following on this issue: Barnett (1989), Block (1988), Buchanan and Thirlby (1981), Buchanan (1969, 1979), Butos and Koppl (1997), Cordato (1989), DiLorenzo (1990), Garrison (1985), Gunning (1990), Kirzner (1986), Mises (1998 [1949]), Rizzo (1979a, 1980), Rothbard (1979, 1997), Stringham (2008).

${ }^{12}$ Whether a private party or the government.

${ }^{13}$ For an Austrian critique of this legislation see Anderson, et. al. (2001), Armentano (1972, 1982, 1989, 1999), Armstrong (1982), Barnett, et al. (2005, 2007), Block (1977, 1982, 1994), Block and Barnett (2009), Boudreaux and DiLorenzo (1992), Costea 


\section{CONCLUSION}

Does the triviality objection pose any problems for Austrian subjectivism?

We contend that the answer to the above question is 'not at all.' Quite the reverse, once we construe the same economic good as this class of items that are perceived as serving the same ends, these being specified intensionally, we predict that there can be such economic actors for whom perfect economic homogeneity or perfect heterogeneity of goods will hold.${ }^{14}$ In fact, Austrians believe that any human action demonstrates heterogeneity of goods even if they are physically indistinguishable.

Finally, perfect heterogeneity and perfect homogeneity must be a part and parcel of Austrian subjectivism. Certainly, since economic actors usually exhibit some finer discriminatory abilities (they frame ends more specifically), these two extremes are expected to be rarely instantiated. ${ }^{15}$

\section{REFERENCES}

Anderson, William, Walter E. Block, Thomas J. DiLorenzo, Ilana Mercer, Leon Snyman and Christopher Westley. 2001. "The Microsoft Corporation in Collision with Antitrust Law," Journal of Social, Political and Economic Studies 26, no. 1: 287-302.

Anderson, William L. 2001. "The Limits of Mathematics" November 29. Available at https:/ / mises.org/library/limits-mathematics.

Anderson, William. 2002. "Mathematics and Economic Analysis." April 02. Available at https://mises.org/library/ mathematics-and-economic-analysis.

(2003), DiLorenzo (1996), DiLorenzo and High (1988), Henderson (2013), High (1984-1985), Hull (2005), McChesney (1991), McGee (1958), Rothbard (2004), Shughart (1987), Smith (1983), Tucker (1998a, 1998b).

${ }^{14}$ Neither is likely, but it does not constitute a logical contradiction to posit it exists.

${ }^{15}$ To reiterate, heterogeneity is ubiquitous-any human action evidences it. After all, the claim that two items are the same economic good cannot be demonstrated in action. But two means can constitute the same economic good if they are believed to be equally serviceable with respect to some end/ends. 
Armentano, Dominick T. 1972. The Myths of Antitrust. New Rochelle, N.Y.: Arlington House.

—. 1982. Antitrust and Monopoly: Anatomy of a Policy Failure. New York: Wiley

- 1989. "Antitrust Reform: Predatory Practices and the Competitive Process," Review of Austrian Economics 3: 61-74. http://www.mises. org/journals/rae/pdf/rae3_1_4.pdf

—. 1999. Antitrust: The Case for Repeal. Revised 2nd ed., Auburn, Ala.: Mises Institute.

Armstrong, Donald. 1982. "Competition versus Monopoly: Combines Policy in Perspective." Fraser Institute: Vancouver, BC, Canada

Barnett II, William. 1989. "Subjective Cost Revisited," Review of Austrian Economics 3: 137-138.

—. 2003. "The Modern Theory of Consumer Behavior: Ordinal or Cardinal?" Quarterly Journal of Austrian Economics 6, no. 1: 41-65.

—. 2004. "Dimensions and Economics: Some Problems," Quarterly Journal of Austrian Economics 7, no. 1: 95-104

Barnett, William II, and Walter E. Block. 2006. "Rothbard on V-Shaped Average and Total Cost Curves," Quarterly Journal of Austrian Economics 9, no. 3: 61-66.

—. 2010. "Mises Never Used Demand Curves; Was He Wrong? Ignorant? No: The Antimathematicality of Demand Curves," Dialogue 1: 23-31.

Barnett, William, Walter E. Block and Michael Saliba. 2005. "Perfect Competition: A Case of 'Market-Failure,'” Corporate Ownership and Control 2, no. 4: 70-75.

—. 2007. "Predatory Pricing," Corporate Ownership and Control 4, no. 4: 401-406

Batemarco, Robert. 1985. "Positive Economics and Praxeology: The Clash of Prediction and Explanation," Atlantic Economic Journal 13, no. 2: 31-27.

Block, Walter E. 1973. "A Comment on 'The Extraordinary Claim of Praxeology,' by Professor Gutierrez," Theory and Decision 3, no. 4: 377-387 
—. 1977. "Austrian Monopoly Theory-A Critique," Journal of Libertarian Studies 1, no. 4: 271-279.

—. 1980. “On Robert Nozick's 'On Austrian Methodology.'” Inquiry 23, no. 4: 397-444.

—. 1982. Amending the Combines Investigation Act, Vancouver: Fraser Institute.

- 1988. "Comment on Leland Yeager on Subjectivism," Review of Austrian Economics 2: 199-208.

—. 1994. "Total Repeal of Anti-trust Legislation: A Critique of Bork, Brozen and Posner," Review of Austrian Economics 8, no. 1: 35-70.

—. 1999. "Austrian Theorizing, Recalling the Foundations: Reply to Caplan," Quarterly Journal of Austrian Economics 2, no. 4: 21-39.

—. 2009. "Rejoinder to Hoppe on Indifference," Quarterly Journal of Austrian Economics 12, no. 1: 52-59.

Block, Walter and William Barnett. 2009. "Monopsony Theory," American Review of Political Economy 7, nos. 1, 2: 67-109.

—. 2010. "Rejoinder to Hoppe on Indifference, Once Again," Reason Papers 32: 141-154.

Boudreaux, Donald J., and DiLorenzo, Thomas J. 1992. “The Protectionist Roots of Antitrust," Review of Austrian Economics 6, no. 2: 81-96.

Brätland, John. 2000. "Human Action and Socially Optimal Conservation: A Misesian Inquiry into the Hotelling Principle," Quarterly Journal of Austrian Economics 3, no. 1: 3-26.

Buchanan, James M. 1969. Cost and Choice: An Inquiry into Economic Theory. Chicago: Markham.

—. 1979. "The General Implications of Subjectivism in Economics." In What Should Economists Do? Indianapolis: Liberty Press.

Buchanan, James M. and G. F. Thirlby. 1981. L.S.E. Essays on Cost. New York: New York University Press.

Butos, William and Roger Koppl. 1997. "The Varieties of Subjectivism: Keynes, Hayek on Expectations," History of Political Economy 29, no. 2: 327-359. 
Bylund, Per. 2011. "The 'Mystery' of the Endowment Effect," December 28. Available at https: / / mises.org/library/ mystery-endowment-effect.

Cachanosky, J. C. 1985. “La Ciencia Economica vs. La Economia Matematica I (The Pitfalls of Mathematical Analysis in Economics)," Libertas 3.

— 1986. "La Ciencia Economica vs. La Economia Matematica II (The Pitfalls of Mathematical Analysis in Economics," Libertas 4.

Callahan, Gene. 2001. "Logical Economics vs. Mathematical Economics." February 17. Available at https://mises.org/library/ logical-economics-vs-mathematical-economics.

Cordato, Roy E. 1989. "Subjective Value, Time Passage, and the Economics of Harmful Effects," Hamline Law Review 12, no. 2: 229-244.

Costea, Diana. 2003. "A Critique of Mises's Theory of Monopoly Prices," Quarterly Journal of Austrian Economics 6, no. 3: 47-62.

DiLorenzo, Thomas J. 1990. “The Subjectivist Roots of James Buchanan's Economics," Review of Austrian Economics 4: 180-195

—. 1996. "The Myth of Natural Monopoly," Review of Austrian Economics 9, no. 2: 43-58.

DiLorenzo, Tom and Jack High. 1988. "Antitrust and Competition, Historically Considered," Economic Inquiry 26, no. 1: 423-435.

Fox, Glenn. 1992. "The Pricing of Environmental Goods: A Praxeological Critique of Contingent Valuation," Cultural Dynamics 5, no. 3: 245-259.

Garrison, Roger. 1985. "A Subjectivist Theory of a Capital Using Economy." In O'Driscoll, Gerald P. and Rizzo, Mario, eds., The Economics of Time and Ignorance. Oxford: Basil Blackwell.

Gunning, J. Patrick. 1990. The New Subjectivist Revolution: An Elucidation and Extension of Ludwig von Mises's Contribution to Economic Theory. Savage, MD: Rowan and Littlefield.

Hayek, Friedrich A. 1979. The Counter-Revolution of Science, 2nd ed. Indianapolis, IN: LibertyPress.

Hazlitt, Henry, 1959. The Failure of the "New Economics." New Rochelle, N.Y.: Arlington House.

Henderson, David R. 2013. “The Robber Barons: Neither Robbers nor Barons." Library of Economics and Liberty. March 4. Available at 
https: / / www.econlib.org / library / Columns / y2013 / Hendersonbarons.html.

Herbener, Jeffrey M. 1996. "Calculation and the Question of Mathematics," Review of Austrian Economics 9, no. 1: 151-162.

High, Jack. 1984-1985. “Bork's Paradox: Static vs Dynamic Efficiency in Antitrust Analysis," Contemporary Policy Issues 3: 21-34.

Hoppe, Hans-Hermann. 1989. "In Defense of Extreme Rationalism: Thoughts on Donald McClosky's The Rhetoric of Economics," Review of Austrian Economics 3: 179-214.

Hoppe, Hans-Hermann. 1991. "Austrian Rationalism in the Age of the Decline of Positivism," Journal des Economistes et des Etudes Humaines 2, no. 2; reprinted as Hoppe, Hans-Hermann. 1994. "Austrian Rationalism in the Age of the Decline of Positivism." In Richard M. Ebeling, ed., Austrian Economics: Perspectives on the Past and Prospects for the Future, vol. 17. Hillsdale, Mich.: Hillsdale College Press, pp. 59-96.

1992. “On Praxeology and the Praxeological Foundation of Epistemology and Ethics." In Herbener, J., ed., The Meaning of Ludwig von Mises. Boston: Dordrecht.

—. 1995. Economic Science and the Austrian Method. Auburn, Ala.: Ludwig von Mises Institute.

—. 2006. "Austrian Rationalism in the Age of the Decline of Positivism." In The Economics and Ethics of Private Property: Studies in Political Economy and Philosophy, 2nd ed., pp. 347-379; Auburn Ala.: Mises Institute

Hull, Gary, ed. 2005. The Abolition of Antitrust. New Brunswick, N.J.: Transaction.

Hülsmann, Jörg Guido. 1999. "Economic Science and Neoclassicism," Quarterly Journal of Austrian Economics 2, no. 4: 1-20.

Hutt, William H. 1979. The Keynesian Episode: A Reassessment. Indianapolis, Ind.: Liberty Press.

Jablecki, Juliusz. 2007. "How Many Traders Can You Fit into a Model?" August 23. Available at https://mises.org/library/ how-many-traders-can-you-fit-model.

Kirzner, Israel M., ed. 1986. Subjectivism, Intelligibility and Economic Understanding. New York: New York University Press. 
— 1990. "The 'Austrian' Perspective on the Crisis." In S. Littlechild, ed., Austrian Economics, vol. 1. Aldershot U.K.: Edward Elgar, pp. 191-202.

Leoni, Bruno, and Frola, Eugenio. 1977. “On Mathematical Thinking in Economics," Journal of Libertarian Studies 1, no. 2: 101-110.

Levinovitz, Alan Jay. 2016. "The New Astrology," April 4. Available at https: / / aeon.co/ essays / how-economists-rode-maths-to-becomeour-era-s-astrologers.

Machaj, Mateusz. 2007. “A Praxeological Case for Homogeneity and Indifference," New Perspectives on Political Economy 3, no. 2: 231-238.

McChesney, Fred. 1991. “Antitrust and Regulation: Chicago's Contradictory Views," Cato Journal 10, no. 3: 775-798.

McGee, John S. 1958. "Predatory Price Cutting: The Standard Oil (New Jersey) Case," Journal of Law and Economics 1: 137-169.

Menger, Karl. 1973. "Austrian Marginalism and Mathematical Economics.” In John R. Hicks and Wilhelm Weber, eds., Carl Menger and the Austrian School of Economics. Oxford: Clarendon Press.

Mises, Ludwig von. 1949. Human Action, Scholars' Edition. Auburn, Ala.: Mises Institute, 1998.

- 1969. Theory and History: An Interpretation of Social and Economic Evolution. New Rochelle, N.Y.: Arlington House.

- 1977. "Comments about the Mathematical Treatment of Economic Problems," Journal of Libertarian Studies 1, no. 2: 97-100.

Murphy, Robert P. 2008. “Austrian Realists.” July 17. Available at https: / / mises.org/library/austrian-realists.

Murphy, Robert P., Robert Wutscher, and Walter E. Block. 2010. "Mathematics in Economics: An Austrian Methodological Critique," Philosophical Investigations 33, no. 1: 44-66.

Nozick, Robert. 1977. “On Austrian Methodology,” Synthese 36: 353-392.

—. 1997. "On Austrian Methodology." In Socratic Puzzles. Cambridge: Harvard University Press.

Pfleiderer, Paul. 2014. "Chameleons: The Misuse of Theoretical Models in Finance and Economics." Stanford Graduate School of Business Working Paper No. 3020. Available at https:// 
www.gsb.stanford.edu / faculty-research / working-papers / chameleons-misuse-theoretical-models-finance-economics.

Polleit, Thorsten. 2008. "Mises's Apriorism Against Relativism in Economics." April 25. Available at https://mises.org/library/ misess-apriorism-against-relativism-economics.

—. 2011. "True Knowledge from A Priori Theory." June 8. Available at https: / / mises.org/library / true-knowledge-priori-theory.

Reekie, W. Duncan. 1984a. “The Austrian Response at a Micro Level." In Markets, Entrepreneurs, and Liberty. Brighton, Sussex, U.K.: Wheatsheaf Books, pp. 27-55.

—. 1984b. "The Austrian Macro Retort." In Markets, Entrepreneurs, and Liberty. Brighton, Sussex, U.K.: Wheatsheaf Books, pp. 56-84

Rizzo, Mario J. 1979a. "Uncertainty, Subjectivity, and the Economic Analysis of Law." In Mario J. Rizzo, ed., Time, Uncertainty, and Disequilibrium. Lexington, Mass.: Lexington Books, pp. 71-90.

- 1979b. "Praxeology and Econometrics: A Critique of Positivist Economics." In Louis Spadaro, ed., New Directions in Austrian Economics. Kansas City: Sheed Andrews and McMeel, pp. 40-56.

—. 1980. "The Mirage of Efficiency," Hofstra Law Review 8: 641-658.

Röpke, Wilhelm, 1956. "The Place of Economics Among the Sciences.” In Mary Sennholz, ed., On Freedom and Free Enterprise. Princeton, N.J.: D. Van Nostrand, pp. 111-127.

Rothbard, Murray N. 1951. "Praxeology: Reply to Mr. Schuller," American Economic Review 41, no. 5: 943-946.

- 1957. "In Defense of Extreme Apriorism," Southern Economic Journal 23, no. 1: 314-320.

- 1960. "The Mantle of Science." In Murray N. Rothbard, The Logic of Action One: Method, Money, and the Austrian School. Cheltenham, U.K.: Edward Elgar, 1997: 3-23.

- 1962. Man, Economy and State, Scholar's Edition. Auburn Ala.: Ludwig von Mises Institute, 2004.

—. 1971. "Lange, Mises and Praxeology: The Retreat from Marxism." In Friedrich A. Hayek, Henry Hazlitt, Leonard R. Read, Gustavo 
Velasco, and F.A. Harper, eds., Toward Liberty, vol. 2. Menlo Park, Calif.: Institute for Humane Studies, pp. 307-321. Reprinted in Murray N. Rothbard, The Logic of Action One: Method, Money, and the Austrian School. Gloucester, U.K.: Edward Elgar, 1997, pp. 384-396.

—. 1973. "Praxeology and the Method of Economics." In M. Natanson, ed., Phenomenology and the Social Sciences, Evanston, Ill.: Northwestern University Press, vol. 2, pp. 311-342; and Richard M. Ebeling, ed., Austrian Economics: A Reader, vol. 18. Hillsdale, Mich.: Hillsdale College Press, 1991, pp. 55-91.

—. 1979. "Comment: The Myth of Efficiency." In Mario J. Rizzo, ed., Time, Uncertainty, and Disequilibrium. Lexington, Mass.: Lexington Books, pp. 91-96.

- 1988. "Chaos Theory: Destroying Mathematical Economics from Within?" The Free Market 6, no. 3. Available at https://mises.org/ library / chaos-theory-destroying-mathematical-economics-withinfull-edition.

—.1993. Man, Economy, and State. Auburn, Ala.: Ludwig von Mises Institute.

—. 1997a. "Toward a Reconstruction of Utility and Welfare Economics." In Murray N. Rothbard, The Logic of Action One: Method, Money, and the Austrian School. Cheltenham, U.K.: Edward Elgar, 1997, pp. 211-254.

—. 1997b. "Praxeology: The Methodology of Austrian Economics." In Murray N. Rothbard, The Logic of Action One: Method, Money, and the Austrian School. Cheltenham, U.K.: Edward Elgar, pp. 58-77.

—. 1997c. "Praxeology, Value Judgments, and Public Policy." In Murray N. Rothbard, The Logic of Action One: Method, Money, and the Austrian School. Cheltenham, U.K.: Edward Elgar, pp. 78-99.

—. 1997d. "In Defense of 'Extreme Apriorism,'” In Murray N. Rothbard, The Logic of Action One: Method, Money, and the Austrian School. Cheltenham, U.K.: Edward Elgar, pp. 100-108.

—. 2011a. "Daniel Bernoulli and the Founding of Mathematical Economics." February 10. Available at: https://mises.org/library/ daniel-bernoulli-and-founding-mathematical-economics.

—. 2011b. "Praxeology: The Methodology of Austrian Economics." In Murray N. Rothbard, Economic Controversies. Auburn, Ala.: Mises Institute. 
Selgin, George A. 1988. "Praxeology and Understanding: An Analysis of the Controversy in Austrian Economics," Review of Austrian Economics 2: $19-58$

Shostak, Frank. 2002. "What Is Wrong with Econometrics?" April 17. Available at: https: / / mises.org/library/what-wrong-econometrics.

Shughart II, William F. 1987. “Don't Revise the Clayton Act, Scrap It!" Cato Journal 6, no. 3: 925-932.

Smith, Jr., Fred L. 1983. "Why not Abolish Antitrust?," Regulation, Jan-Feb, 23-33.

Spadaro, Louis M. 1956. "Averages and Aggregates in Economics." In Mary Sennholz, ed., On Freedom and Free Enterprise. Princeton, N.J.: D. Van Nostrand Co., pp. 140-160.

Stringham, Edward. 2008. "Economic Value and Cost Are Subjective." In Peter Boettke, ed., The Handbook of Austrian Economics. Cheltenham, U.K.: Edward Elgar.

Syrios, Andrew. 2017. "Economists Are the New Astrologers." August 29. Available at: https://mises.org/wire/ economists-are-new-astrologers.

Tucker, Jeffrey. 1998a. “Controversy: Are Antitrust Laws Immoral?" Journal of Markets \& Morality 1, no. 1: 75-82

—. 1998b. "Controversy: Are Antitrust Laws Immoral? A Response to Kenneth G. Elzinga," Journal of Markets E Morality 1, no. 1: 90-94.

Wiśniewski, Jakub Bożydar. 2014. "The Methodology of the Austrian School of Economics: The Present State of Knowledge." Ekonomia Wroclaw Economic Review 20, no. 1: 39-54.

Wolfram, Stephen. 2002. A New Kind of Science. Champaign, Ill.: Wolfram Media.

Wutscher, Robert. 2005. "Foundations in Economic Methodology: The Use of Mathematics by Mainstream Economics and Its Methodology by Austrian Economics." Unpublished. Available at: https: / / misesmedia.s3.amazonaws.com/Wutscher.pdf.

Wysocki, Igor and Walter E. Block. 2018. "An Analysis of the Supply Curve: Does It Depict Homogeneity among Its Constituent Elements? Another Rejoinder to Nozick," Management Education Science Technology Journal 6 , no. 1: 1-11. 